\title{
Inferior Pancreatico-Duodenal Vein
}

National Cancer Institute

\section{Source}

National Cancer Institute. Inferior Pancreatico-Duodenal Vein. NCI Thesaurus. Code C52692.

A blood vessel running parallel to the inferior pancreatico-duodenal artery that drains blood from the pancreas and duodenum into the splenic vein. 